\title{
Ideological and Political Education Mechanism in Colleges and Universities Based on School- enterprise Cooperation Talents Training
}

\author{
Wencheng Xue \\ Shandong Technology and Business University \\ Yantai, Shandong \\ 264005, China
}

\begin{abstract}
As an important part of China's higher education talents training model, School-enterprise cooperation has received more and more attention and recognition from the society. The ideological and political education in colleges and universities emphasizes school-enterprise cooperation, which aims to strengthen quality of talents training from ideological level, to explore elements of ideological and political education in which corporate culture and campus culture are integrated, and to innovate the benign mechanism of college students' ideological and political education from the perspective of school-enterprise cooperation. This work explained problems existing in the schoolenterprise cooperation work in the ideological and political education, such as the lack of resource advantages and contact between schools and enterprises and the imperfect current situation of the school-enterprise cooperation environment. This work also analyzed design concept of the new educational mechanism and discussed decision-making, incentive, guarantee, process control, motivation and evaluation of college students' ideological and political education mechanism from the perspective of school-enterprise cooperation, providing theoretical support for college students' ideological and political education.
\end{abstract}

Keywords-School-enterprise cooperation; Ideological and political education; Mechanism research

\section{RELATIONSHIP BETWEEN SCHOOL-ENTERPRISE}

COOPERATION AND IDEOLOGICAL AND POLITICAL EDUCATION OF COLLEGE STUDENTS

School-enterprise cooperation can not only build a schoolenterprise cooperation platform, but also establish channels for mutual visits between schools and enterprises. Colleges and universities can organize teachers and students to observe enterprises, experience corporate life, learn corporate culture, enhance the understanding of schools and graduates on the development status and prospects of enterprises and open up management vision of ideological and political stuff in colleges and universities, so as to accurately acquire the talents demand of enterprises and improve the pertinence of college students' employment and the effectiveness of ideological and political education [1]. At the same time, the school-enterprise cooperation provides an internship platform for college students to enhance their future employment expectations. College students can acquire relevant vocational skills, enhance their professional quality, improve their professional

This work is a stage achievement of "Graduate Employment Quality Improvement Project" supported by the 2019 counselor studio of Shandong Technology and Business University. positioning accuracy, and develop a correct employment choice concept through their internship in enterprises, so as to improve their ability to adapt to and integrate into society [2].

\section{CURRENT SituATION OF COLLEGE STUDENTS' IDEOLOGICAL AND POLITICAL EDUCATION FROM THE PERSPECTIVE OF SCHOOL-ENTERPRISE COOPERATION}

\section{A. Current situation of school-enterprise cooperation}

\section{1) Talent training}

As an important base for talents training, colleges and universities shoulder the heavy responsibility of cultivating high-quality and high-skilled talents. The talent cultivation model of school-enterprise cooperation embeds enterprise value and corporate culture into the high-quality talents training system of colleges and universities and accurately cultivates various skilled talents that enterprises really need, so as to achieve the effective integration of knowledge theory and practical skills. Through cultivating students' practical skills and innovation consciousness, it can improve the quality and level of students' employment and alleviate employment pressure of the whole society [3].

\section{2) Scientific research}

In the era of knowledge economy, school-enterprise cooperation, as an important part of the industry-universityresearch cooperation system, has been committed to building a joint scientific and technological cooperation platform and talent training system for colleges and universities and enterprises. Through the establishment of scientific research centers, key laboratories and science parks, scientific research can be carried out and results incubation can be achieved. The continuous development of school-enterprise cooperation is inevitable, that is, colleges and universities can provide technical support for enterprise development, and enterprises can absorb more high-quality talents from colleges and universities through technology research and development, so that the two sides can achieve mutual benefit and win-win [4].

\section{3) Social service}

In recent years, employment pressure of college graduates in China has become increasingly serious. At the same time, the development of real economy is slow. Some enterprises have encountered capital and technical bottlenecks, and the introduction of high-quality talents is difficult. As a result, the 
prospect of school-enterprise cooperation is worrying. China should create conditions to encourage enterprises to carry out school-enterprise cooperation with colleges and universities. If enterprises want to use talents and technological advantages of colleges and universities to seek development, colleges and universities have to develop their social service function. In this way, enterprises are profitable and the cooperation between schools and enterprises can be better and faster [5].

\section{B. Current situation of ideological and political education of college students}

1) Increasing status and emphasis

Since the reform and opening up, the ideological and political education of college students has always been an important education project for the Party and China. Particularly, President Xi Jinping gave an important speech at the national ideological and political conference of colleges and universities and raised the ideological and political education of college students to a new position. It is about the responsibility of national rejuvenation. Colleges and universities should uphold the party's leadership, strengthen and innovate the institutional mechanisms of ideological and political education in colleges and universities, and give play to the important role of ideological and political education in cultivating talents and improving continuous reform and further development of higher education.

\section{2) Perfect system but insufficient development}

With the deepening of economic globalization and political multi-polarization, the idea of cultural pluralism and value diversification has been pouring into China. On the one hand, it has liberated people's thoughts and expanded people's horizons; on the other hand, it has raised more challenges for the ideological and political education of college students. The construction of ideological and political education system in colleges and universities is relatively perfect, and the development of discipline construction, curriculum construction, textbook writing and teaching reform is developing rapidly. The content and system construction of ideological and political education in colleges and universities is becoming more scientific and standardized, however, the development of talents training and team building is insufficient.

\section{3) High professional quality and strong team building}

Party and the government attach great importance to the construction of the ideological and political education work team in colleges and universities and continuously improve the professional quality and political quality of this team, such as constructing platforms of talents training, educational teaching, scientific research, teacher training and business improvement, increasing doctor's and master's degrees conferring units through various forms, selecting business backbone to go abroad for further study, and implementing college counselor's special program for doctoral degree. A specialized, professional and expert team of ideological and political education in colleges and universities is forming.

\section{Main problems existing in ideological and political education work from the perspective of school-enterprise cooperation}

1) School-enterprise cooperation lacks resource advantages

School-enterprise cooperation, as an important platform for ideological and political education in colleges and universities in the new era, is still in the process of exploration and integration. Multiple resources cannot play a comprehensive role. Numerous educational resources, technical resources, information resources, human resources, knowledge resources, public opinion resources and network resources are solely exerted, always focusing on the advantages of a certain resource but ignoring the comprehensive utilization of other resources, which leads to the problem that resource advantages cannot be effectively exerted, and in turn results in insufficient effectiveness of ideological and political education in colleges and universities [6].

\section{2) Schools and enterprises lack contact}

The effective communication and pragmatic connection between colleges and enterprises is related to the success or failure of both schools and enterprises. To a certain extent, it also determines the success or failure of ideological and political education. Lacking effective communication between schools and enterprises not only fails to reach an effective agreement, but also makes school-enterprise cooperation model become a mere formality. Therefore, schools and enterprises have to maintain a high degree of consistency in the methods and concepts of ideological and political education. However, the current contact and communication between schools and enterprises are not smooth enough, which seriously restricts the development of ideological and political education in colleges and universities.

\section{3) School-enterprise cooperation environment needs to be} improved

Under the school-enterprise cooperation mode, the ideological and political education of colleges and universities faces a complex social environment. Advantages and disadvantages of government, society, enterprises, schools, families and other parties directly affect and restrict the implementation environment of ideological and political education in colleges and universities. At present, environmental laws and regulations in China are still not sound enough, since they lack necessary legal environment. Social recognition and acceptance of school-enterprise cooperation is not high enough, resulting in a lack of social environment. In addition, enthusiasm of students to participate is not high, resulting in the entire unsatisfactory school-enterprise cooperative environment.

\section{RESEARCH ON THE IDEOLOGICAL AND POLITICAL} EDUCATION MECHANISM OF COLLEGE STUDENTS FROM THE

PERSPECTIVE OF SCHOOL-ENTERPRISE COOPERATION

\section{A. Construction of incentive mechanism}

\section{1) Construction requirements}

In terms of the function, school-enterprise cooperation has to play an all-round incentive role, which has functional advantages and exerts comprehensive incentive function from 
both the material and spiritual levels. In terms of the effect, school-enterprise cooperation has to carry out the effectiveness of ideological and political education, and makes both college students and employees feel the benefits of ideological and political education. In terms of the level, school-enterprise cooperation has to take into account the interests of enterprises, colleges and universities and society [7].

\section{2) Mechanism conception}

The construction of an educational mechanism should first establish a comprehensive incentive mechanism. Whether it is mental or material, psychological or behavioral, it must form a comprehensive incentive, which is conducive to strengthening the cooperation between schools and enterprises and improving the effect of ideological and political education in colleges and universities from the perspective of school-enterprise cooperation. Second, it should establish an incentive mechanism from multiple sides. It should not only achieve incentives for colleges and universities and related companies, but also for all sectors of society. In order to realize this goal, it should actively mobilize the main body of all parties, enhance the incentive concept, and use incentive mechanisms to enhance the work of ideological and political education in colleges and universities.

\section{3) Mechanism construction content}

First, incentive institution. It mainly refers to the special committees for school-enterprise cooperation, specialized offices, joint working groups, and ideological and political education departments under the school-enterprise cooperation mechanism. Second, incentive method. Material level is a relatively common reward method, which gives mainly bonuses, materials, salary and other circumstances. Spiritual reward is a high-level reward method, which mainly gives trophies, certificates, model soldiers and moving characters. Third, incentive model. It mainly gives incentives to advanced people and punishment incentives to laggards. Fourth, incentive measure. It refers to measures and steps of implementing incentives.

\section{B. Construction of decision mechanism}

\section{1) Construction requirements}

In terms of function, the decision-making mechanism of school-enterprise cooperation should fully collect student suggestions, visit the employment market, collect the needs of all parties and draw on the wisdom of the masses to make decisions that are in line with the interests of both parties. At the same time, it should realize organizational coordination function and implementation function. In terms of effect, the construction of the mechanism should realize the form construction, play the actual function of the decision-making mechanism and eliminate the phenomenon of holding a job without doing work. In terms of level, the construction of the mechanism should not only consider schools and enterprises, but also take into account the decision-making function of the government and enterprises, and integrate decision-making mechanism of school-enterprise cooperation into it.

\section{2) Mechanism conception}

The decision-making mechanism should achieve sound institutions, including the leadership, supervision, management, communication, and decision-making agencies of the schoolenterprise cooperation. It should also achieve a clear goal, which means that school-enterprise cooperation should have specific service objectives. The decision-making mechanism of ideological and political education from the perspective of school-enterprise cooperation is to enhance and improve the quality and level of ideological and political education in colleges and universities. Decision-making mechanisms must be scientific and efficient, and the ideological and political education work in colleges and universities should also attach great importance to efficiency.

\section{3) Mechanism construction content}

First, establishing a school-enterprise cooperation work council. Educational development steering committee should be established in the council system to achieve expected goals of ideological and political education work in colleges and universities through decision support system, decision-making consultation system, evaluation system, supervision system and decision feedback system of school-enterprise cooperation. Second, establishing school-enterprise cooperation joint meeting. Relevant personnel of school-enterprise cooperation organize the ideological and political education work steering group, organize joint meetings and formulate overall planning, resource allocation and safeguard measures for ideological and political education in order to ensure relevant organizations to generate effective decision-making opinions. Third, building an efficient communication network. It mainly includes telephone communication system, liaison communication system and network communication system.

\section{Construction of educational motivation mechanism}

\section{1) Construction requirements}

In terms of function, the motivation mechanism of schoolenterprise cooperation should fully mobilize the enthusiasm of schools and enterprises, as well as the enthusiasm of students to participate, and even the enthusiasm of government, so as to ensure the realization of the interest from all parties. In terms of effect, the motivation mechanism of school-enterprise cooperation should truly exert its practical functions to promote the maximization of the interests of school-enterprise cooperation and realize a new leap in the quality of talents training in colleges and universities. In terms of level, the motivation mechanism should fully consider the interests pursuit of all parties, for instance, the government pursues social development, the cooperative enterprises pursue maximum benefits, and the cooperative universities pursue cooperation and education.

\section{2) Mechanism conception}

One is the dual-subject motivation mechanism, which regards both enterprises and colleges and university as dual subjects of the ideological and political education. It explores cooperation objectives between the two main bodies and builds a dual-subject motivation mechanism. The other is the comprehensive motivation mechanism, which affirms all positive factors that can promote the ideological and political education work in colleges and universities, and regards it as an indispensable driving factor. It forms an all-round driving force, thus realizing the smooth development and quality improvement of ideological and political education in colleges 
and universities from the perspective of school-enterprise cooperation.

\section{3) Mechanism construction content}

First of all, establishing the motivation mechanism that takes enterprises as main body. School-enterprise cooperation is conducive to realizing interest appeals. First, it can realize the exchange of technology and intellectual property rights of enterprises; secondly, it can realize the interactive training of enterprise employees and talents in colleges and universities; third, it can complete relevant $R \& D$ plans and project expectations of the enterprise; finally, it can realize the strategic cooperation between enterprises and universities. In addition, establishing the motivation mechanism that takes colleges and universities as main body. Colleges and universities aim to cultivate high-quality talents, improve employment rate, improve research capabilities, complete relevant research topics and obtain research funding. Finally, establishing the motivation mechanism that takes students as main body. It should improve students' ability and quality, moral quality as well as communicative and practical skills.

\section{SUMMARY}

School-enterprise cooperation, as the source of theoretical innovation in ideological and political education, is mainly reflected in the innovation and development of five aspects: educational philosophy, educational content, educational model, educational method and education system. Chinese enterprises have a unique education mode and education system, which can fill the gaps of educational achievements in the classroom teaching. They can broaden the extension of ideological and political education theory and deepen its connotation. Carrying out ideological and political education through schoolenterprise cooperation has broken through the traditional education mode of higher education, that is, the teaching mode of classroom infusion, enriched the carrier of ideological and political education practice, and highlighted independence and subjective status of college students through establishing incentive mechanism, decision-making mechanism and educational motivation mechanism, providing a practical carrier for the theoretical innovation of ideological and political education.

\section{ACKNOWLEDGMENT}

This work is a stage achievement of "Graduate Employment Quality Improvement Project" supported by the 2019 counselor studio of Shandong Technology and Business University

\section{REFERENCES}

[1] Hu Tingyong, Xu Jinyi. Practice and Thoughts on the Integration of Applied Talents into Ideological and Political Education[J]. Journal of Jishou University (Social Science Edition), 2018(S1).

[2] Huang Weiping. Research on the Construction of College Students' Ideological and Political Education Base from the Perspective of SchoolEnterprise Cooperation[J]. Education Review, 2017(5).

[3] Zhang Hongying. Research on the Path of Strengthening College Students' Ideological and Political Education Based on the Schoolenterprise Cooperation Mode[J]. Intelligence, 2017(5).

[4] Dong Lina. Building a College Students' Ideological and Political Education Mechanism Based on School-enterprise Cooperation[D]. Northeast Petroleum University, 2012. Academic Forum

[5] Zhu Yixin. Application of Humanistic Management Thought in College Student Management[J]. Journal of East China Shipbuilding School, 2001(3).

[6] Zhao Pengfei. Exploration of College Student Management Work Mode in the New Period[J]. Journal of China Women's University, 2002(5).

[7] Zhao Haitao. Innovation of College Student Work in the New Situation[J]. China Adult Education, 2008(9) 